\section{Canadian Institute of Forestry Rules and Regulations Adopted 1982}

\section{Committees and Working Groups}

1.1. Executive Committee (Elected - Ref. By-law 6.5.2.) 1.1.1. The Executive Committee shall guide, direct and otherwise assist the Executive Director in conducting the affairs of the Institute.

1.1.2. The Executive Committee shall act as a Trustee Board for the administration of Pension Funds established for the benefit of employees of the Institute.

1.1.3. At least three meetings of the Executive Committee shall be held each year.

1.2. National Committees (appointed)

1.2.1. National Committees will consist of Technical Affairs Committees, Institute Affairs Committees and Special Committees.

1.2.2. National Committees may be established from time to time by the Board of Directors or the Executive Committee.

1.2.3. Chairmen of Committees will be appointed by the President.

1.2.4. Terms of office may be established by mutual agreement between the President and the Committee Chairman, and are renewable on the mutual agreement of the Board of Directors and the Chairman concerned.

1.2.5. Terms of reference may be established by the Board of Directors, the Executive Committee, the President in consultation with the Committee Chairman or as outlined in the By-laws or these Rules and Regulations. Specific terms of reference will be made at the time of, or prior to, establishment of committees.

1.2.6. Members of Committees will be appointed by the President in consultation with the Committee Chairman.

1.2.7. Terms of reference and Committee membership shall be reviewed by the Executive Committee regularly and by the Board of Directors annually.

1.2.8. Institute funds may be authorized by the Executive Committee to finance Committee projects.

1.2.9. Every Committee will submit a written report for the Board of Directors, to the Executive Director seven weeks prior to each Annual Meeting. Committee Chairmen will report to the Executive Committee on request.

1.2.10. The Executive Director is an ex-officio member of all appointed National Committees.

1.2.11. Any appointed committee may be discharged by the Board of Directors, normally at the end of an Annual Meeting.

1.3. Technical Affairs Committee

1.3.1. Terms of office will normally be three years.

1.3.2. General terms of reference are:

1.3.2.1. To report on developments and progress in forest oriented activities.

1.3.2.2. To stimulate thought, study and discussion.

1.3.2.3. To suggest means by which the practice of forestry may be improved and strengthened.

1.3.2.4. To assist in locating speakers for and arranging sessions at meetings.

1.4. Institute Affairs Committees

1.4.1. Terms of office will normally be one year.

1.4.2. General terms of reference are:

1.4.2.1. To facilitate Institute business.

\section{Institut Forestier du Canada Règles de Pratique Adoptées en 1982}

\section{Comités et groupes de travail}

1.1. Comité exécutif (Elu - Réf. Règlements (6.5.2)

1.1.1. Le Comité exécutif guide, dirige et en tout assiste le directeur exécutif en place dans la conduite des affaires de l'Institut.

1.1.2. Le Comité exécutif agit comme curateur du fonds de pension établi pour les employés de l'Institut.

1.1.3. Le Comité exécutif se réunit au moins trois fois par année.

1.2. Comités nationaux (institués).

1.2.1. Les comités nationaux sont: le Comité des Affaires techniques, le Comité des Affaires de l'Institut, des comités spéciaux (ad hoc).

1.2.2. Les comités nationaux peuvent être formés de temps à autre par le Conseil d'administration ou le Comité exécutif.

1.2.3. Les présidents de comités sont nommés par le Président.

1.2.4. La durée d'exercice peut être établie après entente mutuelle entre le Président et le président du comité et elle est renouvelable après entente mutuelle entre le Conseil d'administration et le président du comité concerné.

1.2.5. Le mandat peut être établi par le Conseil d'administration, le Comité exécutif, le Président après consultation avec le président du comité, ou tel que défini par les règlements ou les présentes règles de pratique. Un mandat spécifique est établi au moment de, ou avant la formation des comités.

1.2.6. Les membres des comités sont nommés par le Président après consultation avec le président de chaque comité.

1.2.7. Le mandat et la liste des membres des comités sont revus régulièrement par le Comité exécutif et annuellement par le Conseil d'administration.

1.2.8. Le Comité exécutif peut allouer des fonds de l'Institut pour le financement des activités des comités.

1.2.9. Chaque comité présente un rapport écrit au directeur exécutif pour étude par le Conseil d'administration au moins sept semaines avant chaque assemblée annuelle. Les présidents de comités font rapport au Comité exécutif sur demande.

1.2.10. Le directeur exécutif est d'office un membre de tous les comités nationaux institués.

1.2.11. Tout comité institué peut normalement être dissout par le Conseil d'administration à la fin de l'assemblée annuelle.

1.3. Comités des Affaires techniques.

1.3.1. La durée d'exercice est normalement de trois ans.

1.3.2. Les mandats consistent généralement à:

1.3.2.1. Faire le compte rendu des développements et des progrès dans le domaine forestier.

1.3.2.2. Encourager la réflexion, la recherche et la discussion.

1.3.2.3. Suggérer les moyens susceptibles d'améliorer et de renforcer la pratique de la foresterie.

1.3.2.4. Prêter assistance dans l'organisation de réunions et suggérer des conférenciers.

1.4. Comités des Affaires de l'Institut

1.4.1. La durée d'exercice est normalement d'un an.

1.4.2. Les mandats consistent généralement à:

1.4.2.1. Faciliter les affaires de l'Institut. 
1.4.2.2. To improve administration.

1.4.2.3. To improve efficiency.

1.4.2.4. To improve or increase activities.

1.4.2.5. To improve or increase the effectiveness of the Institute.

1.5. Special Committees (ad hoc)

1.5.1. Terms of office will be relative to the tasks involved.

1.5.2. General terms of reference will be to complete assigned tasks.

1.6. Working Groups

1.6.1. Working Groups will consist of groups of members interested in a particular field of forestry or related field for the purpose(s) of solving problems and collecting, studying, and disseminating information.

1.6.2. A Working Group may be formed by any ten members on request to and sanctioned by the Executive Committee.

1.6.3. Chairmen of Working Groups may be elected by the Working Group or appointed by the President.

1.6.4. Terms of office may be regulated by the Working Group or the President.

1.6.5. Terms of reference may be set by the Working Group or the President.

1.6.6. Membership in the Working Groups will be by choice of the member. Any Institute member may belong to any two Working Groups.

1.6.7. Activities of the Working Groups will be reviewed by the Executive Committee regularly and the Board of Directors annually.

1.6.8. Working Groups will be self-sufficient but funds may be authorized by the Executive Committee when appropriate.

1.6.9. Every Working Group will submit a written report for the Board of Directors, to the Executive Director seven weeks prior to each Annual Meeting. Working Group chairmen will report to the President on request.

1.6.10. The Executive Director is an ex-officio member of all Working Groups.

1.6.11. Any Working Group may be discharged by the Board of Directors, normally at the end of an Annual Meeting.

\section{Publications General}

2.1. The publications issued by the Institute must be authorized by the Executive Committee. Publications of a policy nature may not be distributed or sold without authorization of the Board of Directors.

2.2. The Forestry Chronicle

The Forestry Chronicle is published by the Institute for the edification and enlightenment of the forestry community. The Editor, who is appointed under contract by the Board of Directors, shall have full authority for the editing and production of the magazine with due consideration to the general wishes of the membership. The Contract with the Editor is for one year, but may be renewed annually and terminated by mutual agreement of the Board of Directors and the Editor. The Editor will report regularly, and when requested, to the Executive Committee and annually to the Board of Directors.
1.4.2.2. Améliorer l'administration.

1.4.2.3. Améliorer le fonctionnement.

1.4.2.4. Améliorer ou augmenter les activités.

1.4.2.5. Améliorer ou augmenter l'efficacité de l'Institut.

1.5. Comités spéciaux (ad hoc)

1.5.1. La durée d'exercice varie en relation directe avec les tâches à accomplir.

1.5.2. Les mandats consistent généralement à compléter les tâches assignées.

1.6. Groupes de travail

1.6.1. Les groupes de travail sont formés de membres intéressés à un domaine particulier de la foresterie ou à un domaine connexe dans le but de résoudre certains problèmes et de recueillir, étudier et disséminer l'information.

1.6.2. Un groupe de travail peut être formé de dix membres qui en font la demande et qui obtiennent l'autorisation du Comité exécutif.

1.6.3. Le président d'un groupe de travail peut être élu par les membres du groupe ou nommé par le Président.

1.6.4. La durée d'exercice est établie par le groupe de travail ou par le Président.

1.6.5. Le mandat peut être défini par le groupe de travail ou par le Président.

1.6.6. Tout membre de l'Institut est libre d'adhérer au groupe de travail de son choix. Tout membre peut faire partie de deux groupes de travail.

1.6.7. Les activités des groupes de travail sont passées en revue régulièrement par le Comité exécutif et annuellement par le Conseil d'administration.

1.6.8. Les groupes de travail doivent s'autofinancer mais, lorsqu'il le juge approprié, le Comité exécutif peut leur attribuer des fonds.

1.6.9. Chaque groupe de travail présente un rapport écrit au directeur exécutif pour la considération du Conseil d'administration sept semaines avant la tenue de chaque assemblée annuelle. Les présidents des groupes de travail doivent présenter un compte rendu au Président, s'il en fait la demande.

1.6.10. Le directeur exécutif est d'office membre de tous les groupes de travail.

1.6.11. Tout groupe de travail peut être dissous par le Conseil d'administration, normalement à la fin de l'assemblée annuelle.

\section{Publications - Général}

2.1. Les publications de l'Institut dovient être vérifiées et acceptés par le Comité exécutif. Les publications ayant trait aux politiques de l'Institut ne peuvent être distribuées ou vendues sans l'autorisation du Conseil d'administration. 2.2. La revue: The Forestry Chronicle

Le Forestry Chronicle est publié par l'Institut pour le bénéfice et l'édification de la communauté forestière. L'éditeur, qui est engagé par contrat par le Conseil d'administration, a pleine autorité concernant l'édition et la production de la revue tout en tenant compte des souhaits généraux des membres. Le contrat avec l'éditeur est d'une durée d'un an, mais il peut être renouvelé annuellement ou abrogé après entente mutuelle entre le Conseil d'administration et l'éditeur. L'éditeur fait rapport régulièrement et sur demande au Comité exécutif et, annuellement, au Conseil d'administration. 


\section{Finances}

3.1. National Dues

Active

1 st yr. after forestry degree graduation

(grad 1983) ....................... \$ 54

2nd yr. after forestry degree graduation

(grad 1982) ...................... \$ 59

3rd yr. after forestry degree graduation

(grad 1981) ...................... \$ 66

All other Active Members $\ldots \ldots \ldots \ldots \ldots \ldots \ldots \$ 79$

Affiliate

$1 \mathrm{st}$ yr. after forestry technician graduation

(grad 1983) .......................\$ 54

2nd yr. after forestry technician graduation

(grad 1982) $\ldots \ldots \ldots \ldots \ldots \ldots \ldots \ldots \ldots \ldots \ldots \$ 59$

3rd yr. after forestry technician graduation

(grad 1981) ...................... \$ 66

All other Affiliate Members ................ \$ 73

Members having Retired Status who wish to

receive the Forestry Chronicle ............\$23

Student Members ......................... \$ 23

Sustaining Members (CIF) ................ \$ 25

Sustaining Members (Others) .............. \$200

3.1.1. New Active and Affiliate Members shall be admitted after January 1 st of each year for half dues.

3.1.2. Schedule

A dues notice for the ensuing fiscal year will be mailed to each member on or before April 1, of each year.

3.1.3. Any member dropped for non-payment of dues, according to By-law 4.1.3., and wishing to be reinstated may do so on payment of the full current year's dues plus a $\$ 10.00$ reinstatement fee.

3.2. Section Dues

3.2.1. Section Councils may authorize Head Office to collect Section dues concurrently with national dues

3.2.2. Section Councils wishing this service or those already using it and wishing to change Section dues, must notify Head Office by Dec. 1.

3.2.3. Section dues collected by Head Office will be remitted to the Section between August 1 and December 1 . 3.3. Annual Meeting

3.3.1. A loan to assist in meeting pre-revenue commitments may be made to Host Annual Meeting Planning Committees on the authorization of the Executive Committee.

3.3.2. Any net surplus resulting from the financing of an Annual General Meeting will be divided so that $50 \%$ of the first $\$ 2000$ surplus and $10 \%$ of the surplus in excess of $\$ 2000$ will accrue to the Host Section, and the sum remaining to the National Institute.

3.3.3. Any net deficit resulting from the financing of an Annual General Meeting will be divided, with $10 \%$ to be paid by the Host Section and $90 \%$ by the Institute, on the authorization of the Executive Committee.

3.4. Institute Funds

3.4.1. Two signatures are required on all cheques drawn on the funds of the Institute.

3.4.2. Signing officers are: all members of the Executive Committee, the Executive Director, members of the Finance Committee, and any other CIF members authorized in writing by the President.

3.4.3. Complete records shall be made for each purchase and a receipt obtained.

\section{Finances}

3.1. Cotisations annuelles au niveau national

Membres actifs

1 ère année suivant l'obtention du diplôme en sciences forestières (gradué 1983) ..........\$ 54

2ème année suivant l'obtention du diplôme en sciences forestières (gradué 1982) . ........\$\$ 59

3ème année suivant l'obtention du diplôme en sciences forestières (gradué 1981) . . . . . . \$ 66

Tous les autres membres actifs ............\$ 79

Membres affiliés

1 ère année suivant l'obtention du diplôme en techniques forestières (gradué 1983) ........\$54

2ème année suivant l'obtention du diplôme en techniques forestières (gradué 1982) ........\$ 59

3ème année suivant l'obtention du diplôme en techniques forestières (gradué 1981) .......\$ 66 Tous les autres membres affiliés ............\$73 Membres retraités (qui désirent recevoir

le Forestry Chronicle) $\ldots \ldots \ldots \ldots \ldots \ldots \ldots \ldots \$ 23$ Membres étudiants ....................... \$ 23

Membres auxiliaires (IFC) $\ldots \ldots \ldots \ldots \ldots \ldots \ldots \ldots \$ 25$ Membres auxiliaires (autres) .............. \$200 3.1.1. Tout nouveau membre actif ou affilié admis après le 1 er janvier de chaque année paye une demi-cotisation 3.1.2. Un avis de cotisation pour l'année fiscale suivante est posté à chaque membre au plus tard le 1er avril de chaque année.

3.1.3. Toute adhésion annulée faute de paiement de la cotisation, tel que prévu aux règlements (4.1.3.), peut être renouvelée sur paiement de la cotisation d'une année complète plus un droit de réinscription de $\$ 10$.

3.2. Cotisation de Section

3.2.1. Les Conseils de Section peuvent autoriser le siège social à percevoir les cotisations de section en même temps que la cotisation nationale.

3.2.2. Les Conseils de Section qui désirent profiter de ce service, ou ceux qui en profitent déjà et qui veulent changer la cotisation de Section, doivent en aviser le siège social avant le 1er décembre.

3.2.3. Les cotisations de Section perçues par le siège social sont remises aux Sections entre le 1er août et le 1er décembre.

\subsection{Assemblée annuelle}

3.3.1. Le Comité exécutif peut autoriser un prêt pour aider le comité HAMPCO à rencontrer ses engagements financiers avant l'assemblée annuelle.

3.3.2. Tout surplus provenant des opérations financières d'une assemblée générale annuelle est réparti de façon à ce que $50 \%$ du premier $\$ 2000$ et $10 \%$ du montant excédant $\$ 2000$, soit versé à la Section hôte de l'assemblée et le reste à l'Institut.

3.3.3. Tout déficit provenant des opérations financières d'une assemblée générale annuelle est divisé de façon à ce que 10\% soit assumé par la Section hôte et $90 \%$ par l'Institut, sur autorisation du Comité exécutif.

3.4. Les fonds de l'Institut

3.4.1. Deux signatures sont nécessaires sur tous les chèques émis par l'Institut.

3.4.2. Les officiers qui peuvent signer sont tous les membres du Comité exécutif, le directeur exécutif, les membres du Comité des finances, et tout autre membre de I'IFC détenteur d'une autorisation écrite du Président.

3.4.3. Le directeur exécutif tient un record complet de tous les achats effectués et de tous les reçus émis en faveur de l'Institut. 
3.4.4. The authority to invest funds of the Institute shall be vested, in the Executive Committee, as specified by the By-law 5.6., and Rules and Regulations, Sections 3.4.4.

3.4.5. To provide maximum income and high liquidity, the Institute's working capital shall be invested in Short-Term deposits in a chartered bank or trust company.

3.4.6. The Institute's reserve funds will be invested separate from working capital in risk-free bonds or accounts that can be readily converted at par value.

3.4.7. The Executive Committee shall report annually on its actions respecting Institute investments to the Board of Directors.

\subsection{Subscriptions.}

Annual subscriptions to The Forestry Chronicle will be $\$ 23.00$ in Canada and $\$ 28.00$ in other countries. Subscription price to multi-users (such as libraries) will be $\$ 46.00$ in Canada and $\$ 56.00$ in other countries. The price of single copies not more than two years old shall be $\$ 5.00$ postpaid to any destination, the price of single copies more than two years old shall be $\$ 10.00$ postpaid to any destination.

\section{Miscellaneous}

\subsection{Honorary and Fellow Membership}

Proposals for Honorary and Fellow Membership must be received by the Executive Director by May 1 in order to be considered by the Board of Directors at their next Annual Meeting.

4.2. Resolutions

Resolutions for consideration at an Annual General Meeting, excepting those arising from the business of that meeting and those expressing appreciation, shall be submitted to Head Office by the preceding June 1 ; then forwarded to the Chairman of the Resolutions Committee for study, revision, or approval or rejection as the Committee may deem necessary. The Chairman of the Resolutions Committee shall submit approved resolutions to the Executive Director by the first of August. The Executive Director shall then, without delay, submit approved resolutions to all Directors. 4.3. Awards

4.3.1. Canadian Forestry Achievement Award

Each year nominations submitted on or before May 1 are to be considered by the Executive Committee for the Canadian Forestry Achievement Award. The award to be presented annually or from time to time shall consist of an appropriate award, a certificate, and a citation.

4.3.2. Canadian Forestry Scientific Achievement Award Each year nominations submitted on or before May 1 are to be considered by the Executive Committee for the Canadian Forestry Achievement Award. The award, to be presented annually or from time to time, shall consist of an appropriate award, a certificate, and a citation.

4.3.3. Canadian Institute of Forestry Medals

Medals, one for each professional forestry school in Canada, shall be given annually or from time to time to graduating students who shall be selected by the head of the school and for outstanding scholarship, sports and citizenship recorded throughout all years of the course.
3.4.4. La responsabilité d'investir les fonds de l'Institut est dévolue au Comité exécutif tel qu'indiqué aux règlements (5.6) et aux règles de pratique, section 3.4.4.

3.4.5. Pour s'assurer un revenu maximum et une grande liquidité, le fonds de roulement de l'Institut est investi dans un dépôt à court terme, dans une banque à charte ou un trust.

3.4.6. Le fonds de réserve de l'Institut est investi séparément du fonds de roulement, soit dans des certificats de placement sans risque qui peuvent être encaissés en tout temps à leur valeur au pair, soit dans un ou des comptes de banque.

3.4.7. Le Comité exécutif présente au Conseil d'administration un rapport annuel concernant les investissements de l'Institut.

3.5. Abonnements

Le tarif annuel pour la revue The Forestry Chronicle est de $\$ 23.00$ au Canada et $\$ 28.00$ ailleurs. Le tarif pour les bibliothèques et institutions semblables est de $\$ 46.00 \mathrm{au}$ Canada et $\$ 56.00$ ailleurs. Le prix par copie datant de moins de deux ans est de $\$ 5.00$ port payé toute destination; le prix par copie datant de plus de deux ans est de $\$ 10.00$ port payé toute destination.

\section{Divers}

\subsection{Membres honoraires et émérites}

Les propositions de nomination à titre de membre honoraire et émérite doivent parvenir au bureau du directeur exécutif avant le 1er mai pour que le Conseil d'administration puisse les considérer lors de l'assemblée anriuelle suivante.

4.2. Résolutions

Les résolutions soumises pour étude lors de l'assemblée générale annuelle, à l'exception de celles qui ont une relation directe avec le sujet de l'assemblée et les résolutions dites d'appréciation, doivent parvenir au siège social avant le 1er juin. Elles sont ensuite acheminées au président du comité des résolutions pour étude, révision, approbation ou refus. Le président de ce comité soumet les résolutions approuvées au directeur exécutif avant le 1er août. Ce dernier doit alors, sans délai, soumettre ces résolutions à tous les membres du Conseil d'administration.

4.3. Prix

4.3.1. Prix décerné pour une réalisation exceptionnelle dans le domaine de la foresterie au Canada. Chaque année, les mises en candidature pour ce prix sont soumises au Comité exécutif pour examen avant le 1er mai. Le prix décerné annuellement ou lorsque nécessaire consiste en une récompense appropriée, un certificat et une mention.

4.3.2. Prix décerné pour une réalisation scientifique exceptionnelle dans le domaine de la foresterie au Canada. Chaque année les candidatures pour ce prix sont soumises au Comité exécutif pour examen avant le 1er mai. Le prix, qui est présenté annuellement ou de temps à autre, consiste en une récompense appropriée, un certificat et une mention.

4.3.3. Médailles de I'Institut forestier du Canada Une médaille est décernée annuellement ou de temps à autre dans chacune des facultés de foresterie du Canada à un finissant choisi par le doyen et reconnu pour son dynamisme exceptionnel tout au long de son cours dans les domaines scolaire, sportif et civique. 


\subsubsection{Schlich Memorial Prize}

An award known as the Schlich Memorial Prize and consisting of the accumulation of interest on the Schlich Memorial Fund held in trust by the Institute, shall be given annually or from time to time (and in rotation to each professional forestry school in Canada) to a deserving forestry student as selected by the head of his school.

4.3.5. Foresters' Rings

Foresters' Rings shall be given annually to the forestry baccalaureate graduates of that year of the Canadian Universities.

4.4. Privileges of Sustaining Members

All Sustaining Members shall be listed annually in the Forestry Chronicle and shall receive a special membership card. Sustaining Membership shall in no other way restrict or enhance the rights and responsibilities relating to any other class of membership. Sustaining Members who are not otherwise members of the Institute may enjoy such other benefits and privileges as are approved by resolution of the Institute.

The By-laws are published in English and French. In the case of difficulty in interpretation, the English version is regarded as authorative.
4.3.4. Prix commémoratif Schlich

Une prix en argent équivalent à l'intérêt accumulé dans le fonds commémoratif Schlich, détenu en fiducie par l'Institut et connu sous le nom de Prix commémoratif Schlich, est attribué annuellement ou de temps à autre (en alternant d'une faculté de foresterie à l'autre au Canada) à un étudiant méritant choisi par le doyen.

4.3.5. Joncs d'ingénieurs forestiers

Les joncs d'ingénieurs forestiers sont donnés chaque année à tous les gradués des facultés de foresterie du Canada.

4.4. Privilèges des membres auxiliaires

La liste de tous les membres auxiliaires est publiée chaque année dans le Forestry Chronicle. Ils reçoivent une carte spéciale de membre. La classe de membre auxiliaire ne doit en aucune façon restreindre ou rehausser les droits et responsabilités de toute autre classe de membre. Les membres auxiliaires qui ne sont pas autrement membres de l'Institut peuvent jouir de tout autre bénéfice et privilège approuvé par résolution de l'Institut.

4.5. Les règles de pratique sont rédigées en anglais et en français. En cas de difficulté d'interprétation, la version anglaise est officielle.

Texte traduit de l'anglais par G. Paillé; revu par Claude Turmel et François Matte.

Janvier 1983. 